\title{
Economic Evaluation of Some Soils of Arid Regions of Anantapur District for Groundnut Cultivation
}

\author{
S. Dharumarajan, M. Lalitha, S. C. Ramesh Kumar, R. Vasundhara, V. Ramamurthy, \\ Rajendra Hegde and S. K. Singh ${ }^{1}$
}

\author{
ICAR-National Bureau of Soil Survey and Land Use Planning, Hebbal-560024, Bangalore, India \\ ${ }^{1}$ ICAR-National Bureau of Soil Survey and Land Use Planning, Amravati Road, \\ Nagpur-440033, Maharashtra, India
}

\begin{abstract}
The present study was carried out in Bukkarayasamudhrum mandal of Anantapur district of Andhra Pradesh to assess the economic viability of different soil units for supporting groundnut crop. Advanced remote sensing and GIS technologies were used to map the soil resources at phase level. The non-parametric approach revealed that $57.6 \%$ of the area is moderately suitable for groundnut cultivation and $21 \%$ of area is marginally suitable due to limitation of rooting depth and heavy soil texture. Economic land evaluation results showed that noncalcareous, moderately deep soils with loamy sand surface texture gives comparatively higher benefit cost ratio than other soils.
\end{abstract}

Key words: Soil series, groundnut, land suitability classes, economic evaluation, remote sensing.

\section{Introduction}

Worldwide, there are changes in soil properties and decline in soil quality due to contamination of inorganic and organic chemicals (Arshad and Martin 2002). At the same time, the major challenge is to increase yield to meet the demands for food without compromising the environment. Soil survey is the most common procedure for mapping soil resources which divides the area into parcels of land or mapping units. Maps generated during soil survey not only help in understanding soil genesis and development and also provide information on suitability of soil resources for variety of crops (Dharumarajan and Singh 2014).

Groundnut (Arachis hypogea L.), is a major legume oilseed crop grown in India and accounts for 45 per cent of the total area and 55 per cent of the total production of oilseeds in the country (Madhusudhana

"Corresponding author: (E-mail: sdharmag@gmail.com)
2013). Groundnut is traditionally cultivated as rainfed crop mainly by marginal and small farmers. In India, groundnut yield varies from 550 to $1100 \mathrm{~kg}$ per ha with the total production of 4.3 to 9.6 million tonnes in different years and contributes about $19 \%$ to world groundnut production. Though groundnut is grown on soils varying from black cotton soils to gravelly red soils, generally loose and friable soils are good for pod development. Preferably, sandy and loamy soils are good for groundnut cultivation (Naidu et al. 2006). Waterlogging, poor drainage, sodicity and acidity are major soil constraints for its economic cultivation.

Anantapur, located in Rayalaseema region of Andhra Pradesh is the leading producer of groundnut in India and this region contributes around $3 \%$ to total production of the country. Though this region is agroecologically marginally suitable for rainfed groundnut production, the farmers continue to adopt groundnutbased cropping system (Virmani and Shurpali 1999). 
Hence continuous poor performance of groundnut production over the years caused distress among the farmers community. The major causes for poor performance are erratic rainfall, low soil fertility and low available water holding capacity and poor socio economic condition of marginal and small farmers. In this context, the present study was conducted to evaluate economic suitability of soils of Bukkarayasamudhrum mandal, Anantapur district representing arid region of south India for groundnut cultivation.

\section{Materials and Methods \\ Studyarea}

The study area is located between $13^{\circ} 37^{\prime} 51^{\prime \prime}$ and $14^{\circ} 48^{\prime} 09^{\prime \prime} \mathrm{N}$ and $77^{\circ} 33^{\prime} 47^{\prime \prime}$ and $77^{\circ} 47^{\prime} 45^{\prime \prime} \mathrm{E}$ in Anantapur district of Andhra Pradesh, India (Fig.1). The climate of Bukkarayasamudhrum mandal is warm which is classified as hot arid bioclimatic condition. The average minimum and maximum temperatures are 22.9 and $34^{\circ} \mathrm{C}$, respectively, and average annual rainfall is $556 \mathrm{~mm}$. The total length of growing period (LPG) is less than 90 days. The elevation varies from 295 to $595 \mathrm{~m}$ MSL. The major part of mandal has nearly level to very gentle slope with 1-3 per cent slope.

\section{Datasets used and interpretation}

Landform analysis was carried out using Survey of India toposheets and the contours were generated from the Shuttle Radar Topography Mission Digital Elevation Model (SRTM DEM) using ArcGIS 10 software. Land use/land cover was delineated by onscreen visual interpretation of Resourcesat LISS IV data. The landform, slope, and land-use/land-cover layers were integrated and landform ecological units (LEU) map was generated. The LEU map was used as a base map for ground truth verification and identification of soil profile location.

\section{Surveymethodology}

Preliminary traverse was carried out using LEU map and soil profiles were located based on land surface features such as drainage pattern, slope characteristics and land use (Natarajan and Sarkar 2010). Morphological characteristics of 91 soil profiles were studied as per USDA Soil Survey Manual (Soil Survey Staff 2003). The profiles were grouped into different soil series based on differentiating characteristics. The area under each series was further divided into phases and their boundaries were delineated based on the variations observed in the texture of the surface soil, slope, erosion, presence of gravels and stoniness. Horizon-wise samples were collected for laboratory analysis. In laboratory, particle-size distribution was carried out by International pipette method (Jackson 1973) and organic carbon was estimated by Walkley and Black (1934) method. Soil reaction (1:2.5 soil water suspension), electrical conductivity, cation exchange capacity and exchangeable bases were determined as per Jackson (1973).

\section{Soil suitability evaluation for groundnut crop}

Evaluation of site suitability for groundnut crop was carried out as per FAO framework on land evaluation (FAO 1983) modified by Naidu et al. (2006). Soil characteristics, such as depth, texture, gravelliness, $\mathrm{pH}$ and calcareousness, land features like slope, erosion and drainage and climatic factors such as amount of rainfall and its distribution and length of growing period were used to assess the suitability of land for different crops. To delineate the extent of different suitability classes, "Overlay" analysis concept was used in GIS environment.

\section{Socio economic data collection}

Socio-economic analysis was carried out to evaluate the different soil units for economics of groundnut cultivation under different size classes of farmers. Benefit Cost (B: C) ratio was analysed by collecting detailed information using a structured questionnaire from 100 respondents across the mandal. The sample farmers were classified in to small ( $\leq 2 \mathrm{ha})$, medium ( $>2$ to $\leq 10 \mathrm{ha}$ ) and large ( $>10 \mathrm{ha}$ ) based on their land holding sizes. The cost of cultivation includes cost of inputs such as seed, manure and fertilizers, plantprotection chemicals, payment towards human and bullock labour and interest on working capital. The gross returns were calculated by summing up the value of main product and by-product. By deducting total cost from gross returns, net returns were obtained.

\section{Results and Discussion}

\section{Landform analysis}

Based on the analysis of contour crenulations and the drainage network morphometry as well as the 
photomorphic interpretation of LISS IV image, the study area was classified into 5 landforms viz. Denudational hills in granites and gneisses (structural hills), dissected pediment (low hills/hillocks), pediplain, alluvial deposits and valley. Pediplain covers $49.4 \%$ of the area followed by alluvial deposits (29.2\%) and valley ( 7.8 $\%)$. Dissected pediment and denudational hills occupy $7.2 \%$ of area.

\section{Land use/land cover}

Land use - land cover map of Bukkarayasamudrum mandal was prepared using Resourcesat-2 LISS IV data. The lands with single crop occupy $62.9 \%$ of total geographical area followed by double crop (12.2\%). Scrub lands occupy $6.3 \%$ of area and fallow lands occupy $3.5 \%$ area. The major crops grown were groundnut, pigeon pea, castor, sunflower, pomegranate, citrus and guava.

\section{Land ecological unit}

Based on landform, land use and slope 33 landscape ecological units were delineated in Bukkarayasamudrum mandal. In the denudational hills, three LEUs were identified based on variation in slope ( $E$ and F) and land-use/land-cover classes (forest and scrub). Three LEUs were identified on the dissected pediments and 15 LEUs were identified in the pediplain landform. Alluvial plain was further differentiated into 7 LEUs based on the variation in two slope classes (A and B) and land use (single crop, double crop and fallow).

\section{Soil characterisation and mapping}

The soils of Bukkarayasamudrum mandal were mapped into 8 soil series with 52 phases. Morphological and physico-chemical properties of the representative pedons of soil series are presented in table 1 and 2 .

\section{Chennampalle Series}

Soils of Chennampalle series are shallow (25-50 $\mathrm{cm}$ ), well drained, dark reddish brown, sandy loam in surface, and gravelly sandy clay loam in sub-surface. These soils are very strongly alkaline ( $\mathrm{pH}$ of 9.0-9.16). The organic carbon content varied from 0.54 to $0.84 \%$. The mapping unit $\mathrm{CPb} 2 \mathrm{ER} 4$ covers the largest area followed by CPc2B. These soils are classified as Loamyskeletal, mixed, isohyperthermic Lithic Haplargids and cover $17.1 \%$ of the area.

\section{Venkatapuram Series}

Soils of Venkatapuram series are slightly deep (50-75 cm), well drained, calcareous, yellowish red to dark reddish brown, clayey and are classified as Clayeyskeletal, mixed, isohyperthermic, Typic Haplargids. The mapping unit $\mathrm{VPhA}$ occupies major area. These soils are neutral in surface and slightly to moderately alkaline in sub-surface. Organic carbon content varied from 0.56 to $0.74 \%$ and cation exchange capacity varied from 13.3 to $21.73 \mathrm{cmol}(\mathrm{p}+) \mathrm{kg}^{-1}$.

\section{Dayyadakuntapalle Series}

Soils of Dayyadakuntapalle series are slightly deep, well drained, gravelly reddish brown to yellowish red, fine loamy soils and are classified as Loamyskeletal, mixed, isohyperthermic Ustic Haplargids. The soils cover $13.8 \%$ of total geographical area of Bukkarayasamudrum mandal.

\section{Nilampalle Series}

Soils of Nilampalle series are moderately deep, well drained, gravelly, dark reddish brown to dark red, clayey and are classified as Clayey-skeletal, mixed, isohyperthermic Typic Haplargids. These soils are slightly to moderately alkaline in reaction. Organic carbon content ranged from 0.42 to $0.84 \%$. This soil covers an area of $18.3 \%$ of Bukkarayasamudrum mandal and mapping unit NPhA covers larger area followed by NPh2B.

\section{Rekulakuntapalle Series}

Rekulakuntapalle soils are deep $(100-150 \mathrm{~cm})$, well drained, gravelly, dark red to red clayey and are classified as Clayey-skeletal, mixed, isohyperthermic Ustic Haplargids. Soil pH varied from 7.26 to 7.66 and OC content from 0.39 to $0.91 \%$. The soils cover about 2 $\%$ of total geographical area of Bukkarayasamudrum mandal. Coarse surface texture and gravelliness are the indication that these soils are undergoing moderate to severe erosion (Lalitha et al.2016).

\section{Yadavalaparti Series}

The soils of Yadavalaparti series are slightly deep, well drained, calcareous, dark reddish brown to reddish brown fine-loamy soils and are classified as Fine-loamy, mixed, isohyperthermic Typic Haplargids. These soils are moderately alkaline to strongly alkaline in nature and calcareous. Organic carbon in surface is 
high $(1.3 \%)$ compared to sub-surface. The soils cover an area of about $9.8 \%$ of Bukkarayasamudrum mandal.

\section{Lolluru Series}

Lolluru series are moderately deep, well drained, very dark greyish brown, calcareous clayey soils formed from alluvium and are classified as Fine, mixed, isohyperthermic Typic Haplargids. These soils are calcareous and moderately to very strongly alkaline in reaction. Organic carbon content of the soil ranged from $0.32-0.60 \%$. These soils cover $5 \%$ of the total geographical area of Bukkarayasamudhrum mandal.

\section{Govindapalle Series}

The soils of Govindapalle series are deep, moderately well drained, dark brown to very dark grey clayey and are classified as Fine, mixed, isohyperthermic Ustic Haplargids. These soils are moderately alkaline, calcareous soils and their organic carbon content ranged from $0.22-0.87 \%$. It covers 11.9 $\%$ of total geographic area of Bukkarayasamudrum mandal. Nearly 40 per cent of area is affected by strongly alkaline $\mathrm{pH}(>8.4)$. Improper management practices and faulty irrigation practices are the major cause for increasing $\mathrm{pH}$ in the soil of the mandal.

\section{Land suitability evaluation}

Drastic change in temperature and rainfall over years shows that there is no stable length of growing period for crops which limits the choice of crop (Naveen 1991). Rainfall and length of growing period of the region is moderately suitable for groundnut cultivation. The non-parametric approach revealed that soils of Chennampalle series are marginally suitable to nonsuitable mainly due to factors such as limitation of rooting depth, gravelliness and rockiness. The other soils developed over granitic landforms are moderately suitable due to gravelliness. The soils of Yadavalaparti and Lolluru series are moderately suitable to groundnut cultivation due to limitation of heavy texture. Govindapalle series is marginally suitable due to poor drainage and heavy texture. Date indicated that $57.6 \%$ of area is moderately suitable followed by $21 \%$ of area is marginally suitable and $7.3 \%$ area is non-suitable for groundnut. Though, climate is a major constraint for production of groundnut, adoption of suitable site specific soil and water conservation measures is needed for sustainable production.

\section{Economic evaluation}

The economic evaluation of rainfed groundnut system on different soil units of Bukkarayasamudrum mandal is presented in table 3 and 4 . Average total cost of cultivation for groundnut crop in Bukkarayasamudhrum mandal is Rs. $15,911 \mathrm{ha}^{-1}$. Out of which Rs. 1,711 is cost of owned inputs, Rs. 14,199 is cost of purchased inputs. The total cost includes cost for labour. The groundnut yield in Bukkarayasamudrum mandal varied from 740 to $2470 \mathrm{~kg} \mathrm{ha}^{-1}$ with an average of $1504 \mathrm{~kg} \mathrm{ha}^{-1}$. The average gross return was Rs.48,913 $\mathrm{ha}^{-1}$ and net return is Rs.33,002 $\mathrm{ha}^{-1}$ and the average benefit-cost ratio is 1.99 . Moderately deep soils $(75-100 \mathrm{~cm})$ have a higher B:C ratio of 2.05 compared to that of slightly deep $(50-75 \mathrm{~cm}$, $\mathrm{B}: \mathrm{C}$ ratio $=2.00)$ and shallow soils $(25-50 \mathrm{~cm}, \mathrm{~B}: \mathrm{C}$ ratio $=1.97)$ for groundnut cultivation. Loamy sand surface texture soils had higher B:C ratio (2.42) compared to that of other surface texture soils. Non calcareous soils showed higher B:C Ratio (2.02) compared to calcareous soils (1.95). Slightly gravelliness soils (15-30) recorded higher B:C ratio (2.04) compared to non-gravelly soils (1.98) for groundnut cultivation. Overall, moderately deep gravelly soils with loamy sand surface texture showed more benefits compared to other soils. The mapping units such as $\mathrm{CPb} 2 \mathrm{~B} 1, \mathrm{DPc} 2 \mathrm{~B} 1, \mathrm{NPCB}$ showed $\mathrm{B}$ : $\mathrm{C}$ ratio of more than 2.5 in medium farmers category whereas mapping units like NPc2C1, VphA, NPc2A had high benefits ( $\mathrm{B}: \mathrm{C}$ ratio of $>2.5$ ) in large farmers category.

\section{Conclusion}

The non-parametric approach revealed that soils developed from granitic landform are moderately to not suitable due to problems of rooting depth, gravelliness and rockiness. The soils of alluvial landform are moderately to marginally suitable for groundnut cultivation due to heavy texture of soil. Economic land analysis results showed that non-calcareous, moderately deep soils with loamy sand surface texture recorded comparatively higher $\mathrm{B}: \mathrm{C}$ ratio than other soils. These results can be recommended to the local stakeholders for increasing their economic benefits through selecting suitable land parcels for cultivation of groundnut. 
Economic evaluation of some soils for groundnut

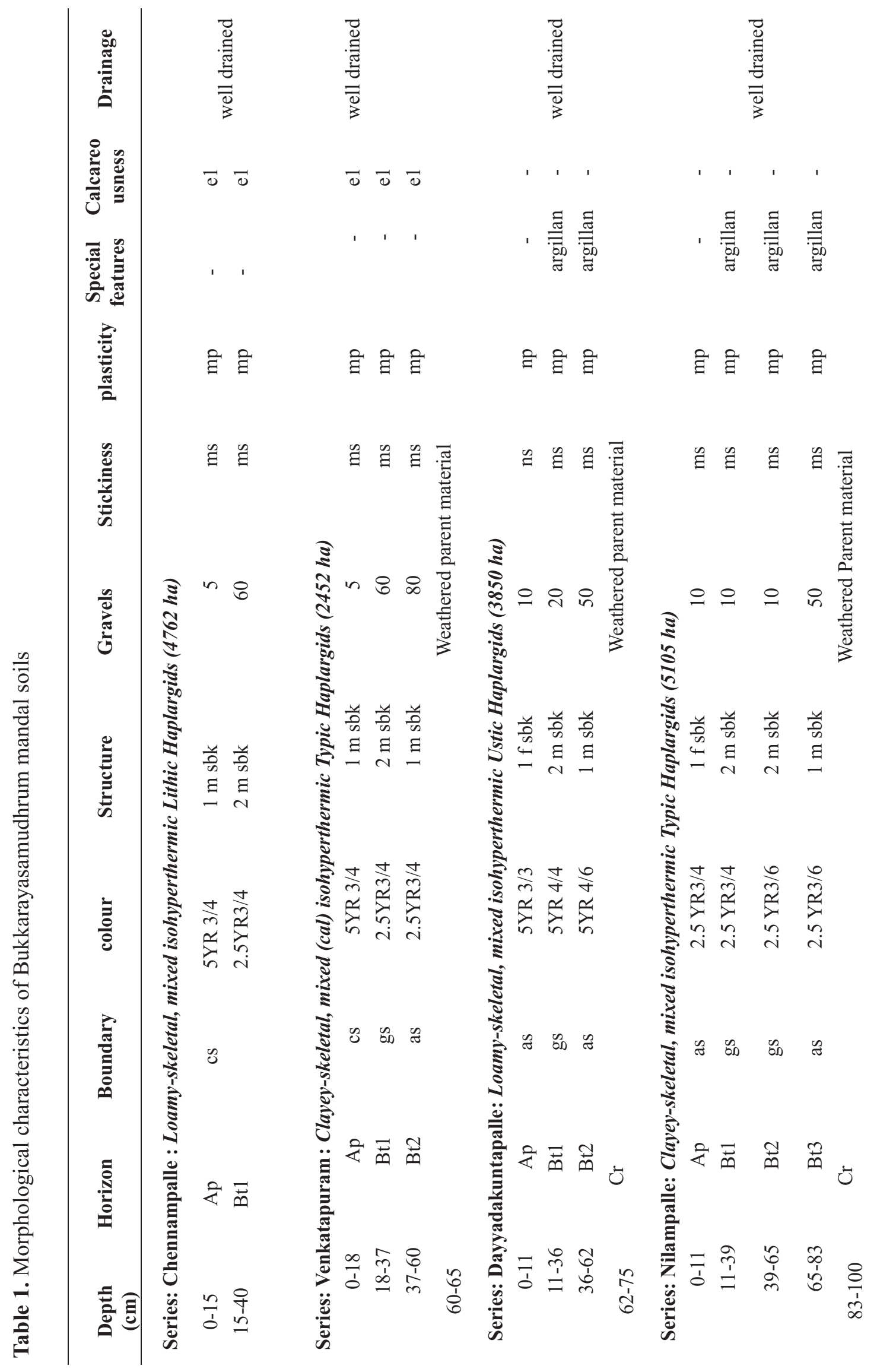




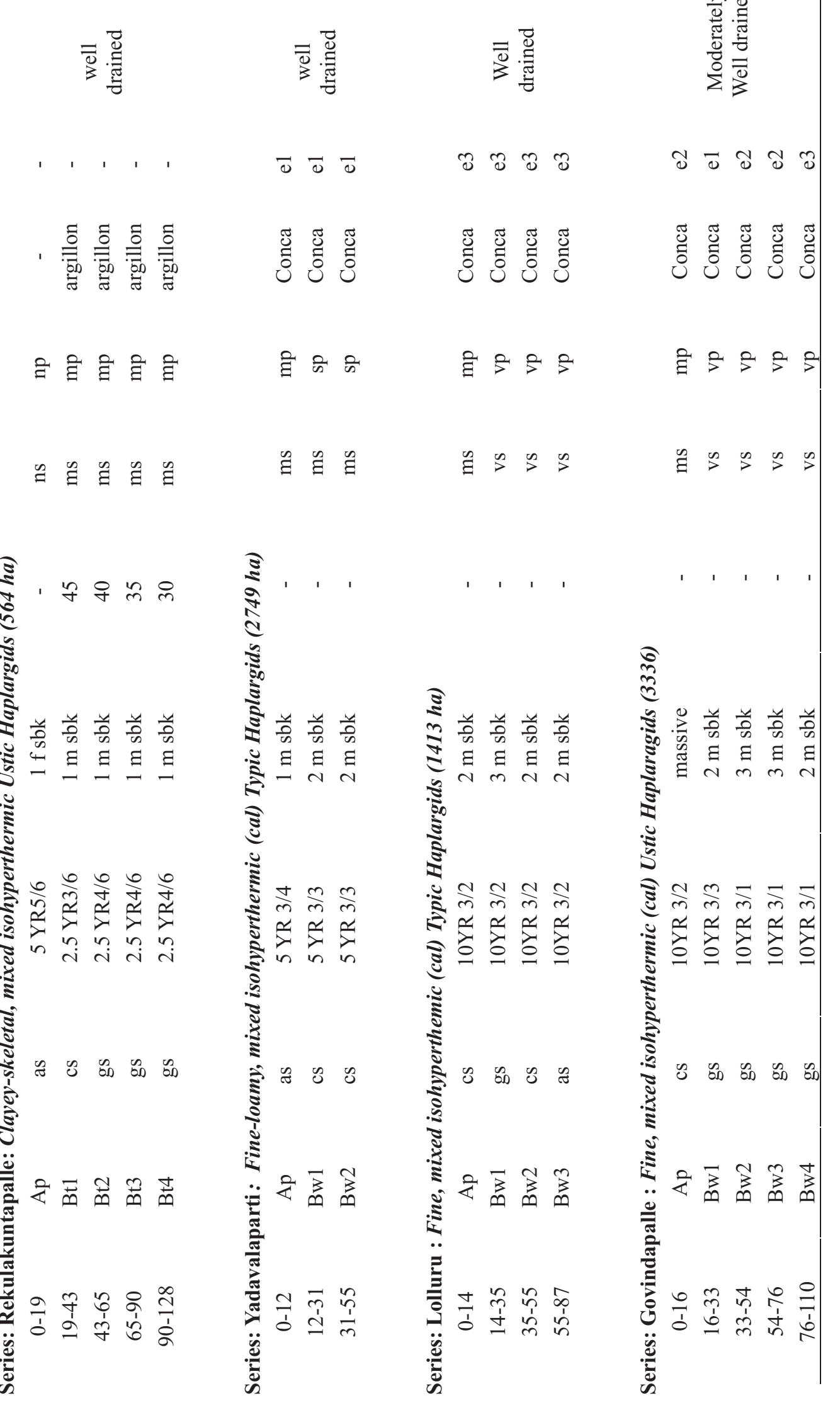




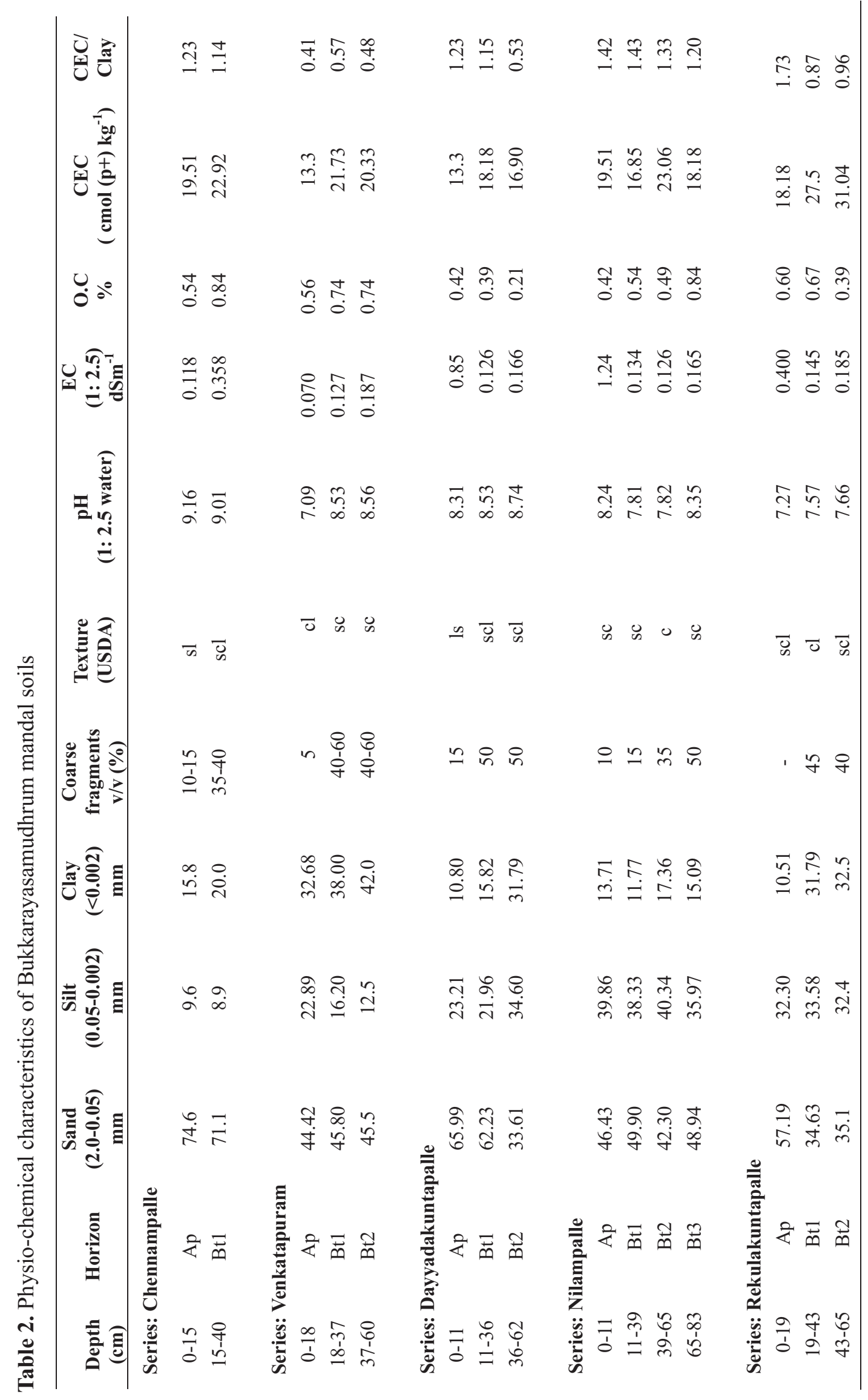




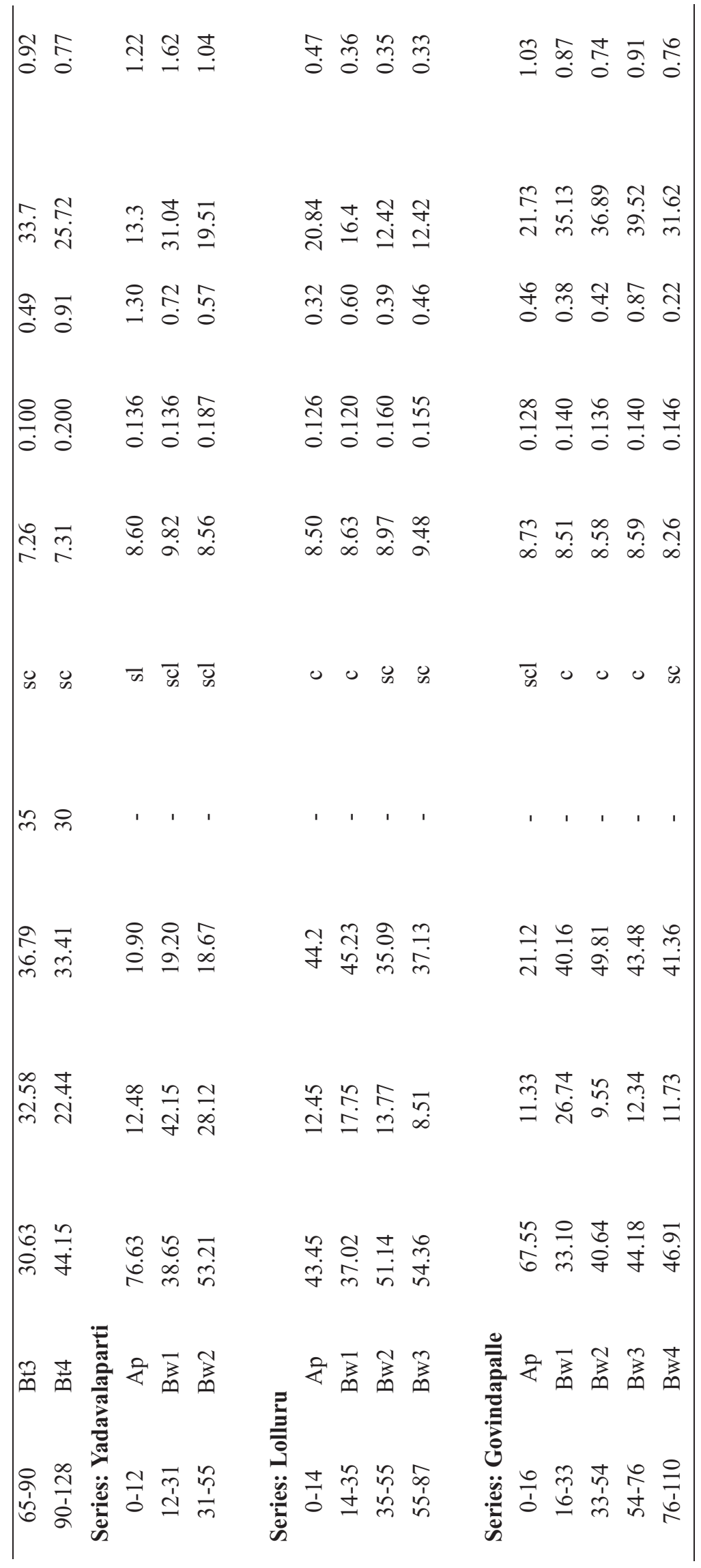


Table 3. Cost of cultivation and net returns for groundnut cultivation in different soil units

\begin{tabular}{|c|c|c|c|c|c|c|c|}
\hline Soil Unit & $\begin{array}{l}\text { Yield } \\
\left(\text { Kgha }^{-1}\right)\end{array}$ & $\begin{array}{c}\text { Gross } \\
\text { Returns } \\
\left(\text { Rsha }^{-1}\right)\end{array}$ & $\begin{array}{c}\text { Total } \\
\text { cost } \\
\left(\text { Rsha }^{-1}\right)\end{array}$ & $\begin{array}{l}\text { Owned } \\
\text { inputs cost } \\
\left.\text { (Rsha }^{-1}\right)\end{array}$ & $\begin{array}{c}\text { Purchased } \\
\text { inputs cost } \\
\left(\text { Rsha }^{-1}\right)\end{array}$ & $\begin{array}{l}\text { Net Returns } \\
\left(\text { Rsha }^{-1}\right)\end{array}$ & $\begin{array}{c}\text { B :C } \\
\text { Ratio }\end{array}$ \\
\hline $\mathrm{CPb} 2 \mathrm{~B} 1$ & 2220 & 69654 & 19693 & 2845 & 16848 & 49961 & 2.5 \\
\hline CPc2B & 1180 & 40490 & 14139 & 1373 & 12766 & 26351 & 1.9 \\
\hline СРc2B1 & 7400 & 22724 & 8981 & 949 & 8031 & 13743 & 1.5 \\
\hline $\mathrm{DPb} 2 \mathrm{~B}$ & 2470 & 75582 & 22785 & 2845 & 19939 & 52797 & 2.3 \\
\hline DPc2B & 820 & 26347 & 8590 & 949 & 7640 & 17757 & 2.1 \\
\hline DPc2B1 & 990 & 37009 & 10260 & 1186 & 9074 & 26749 & 2.6 \\
\hline DPh2B & 780 & 23825 & 11365 & 1140 & 10225 & 12460 & 1.1 \\
\hline $\mathrm{DPhA}$ & 1480 & 45448 & 16519 & 3545 & 12974 & 28929 & 1.8 \\
\hline DPiB1 & 1290 & 40980 & 15671 & 2081 & 13589 & 25309 & 1.6 \\
\hline DPiBi & 1480 & 69983 & 19023 & 251 & 18772 & 50960 & 2.7 \\
\hline GPiA & 1810 & 63201 & 19832 & 1992 & 17841 & 43369 & 2.2 \\
\hline $\mathrm{NPc} 2 \mathrm{~A}$ & 2220 & 69654 & 18113 & 2845 & 15267 & 51541 & 2.8 \\
\hline NPc2B & 740 & 22724 & 13341 & 1773 & 11568 & 9383 & 0.7 \\
\hline $\mathrm{NPc} 2 \mathrm{C}$ & 1480 & 39397 & 14762 & 2309 & 12453 & 24634 & 1.7 \\
\hline $\mathrm{NPc} 2 \mathrm{C} 1$ & 2220 & 99418 & 25413 & 378 & 25035 & 74004 & 2.9 \\
\hline NPCB & 2220 & 69654 & 19302 & 2845 & 16457 & 50352 & 2.6 \\
\hline $\mathrm{NPcC1}$ & 1110 & 29640 & 11548 & 1423 & 10126 & 18092 & 1.6 \\
\hline $\mathrm{NPcC} 2$ & 2220 & 65949 & 19333 & 375 & 18958 & 46616 & 2.4 \\
\hline NPh2B & 2470 & 70642 & 20558 & 2845 & 17713 & 50084 & 2.4 \\
\hline $\mathrm{NPh} 2 \mathrm{~B} 1$ & 2100 & 63232 & 24556 & 2845 & 21711 & 38676 & 1.6 \\
\hline NPHA & 1190 & 37316 & 13320 & 1262 & 12058 & 23996 & 1.8 \\
\hline $\mathrm{RPcC} 2$ & 820 & 25441 & 12263 & 949 & 11314 & 13178 & 1.1 \\
\hline VphA & 870 & 32975 & 11768 & 711 & 11057 & 21207 & 1.8 \\
\hline YPhA & 1030 & 31163 & 10803 & 1186 & 9617 & 20360 & 1.9 \\
\hline YPmA & 1650 & 50388 & 15840 & 1897 & 13943 & 34548 & 2.2 \\
\hline
\end{tabular}




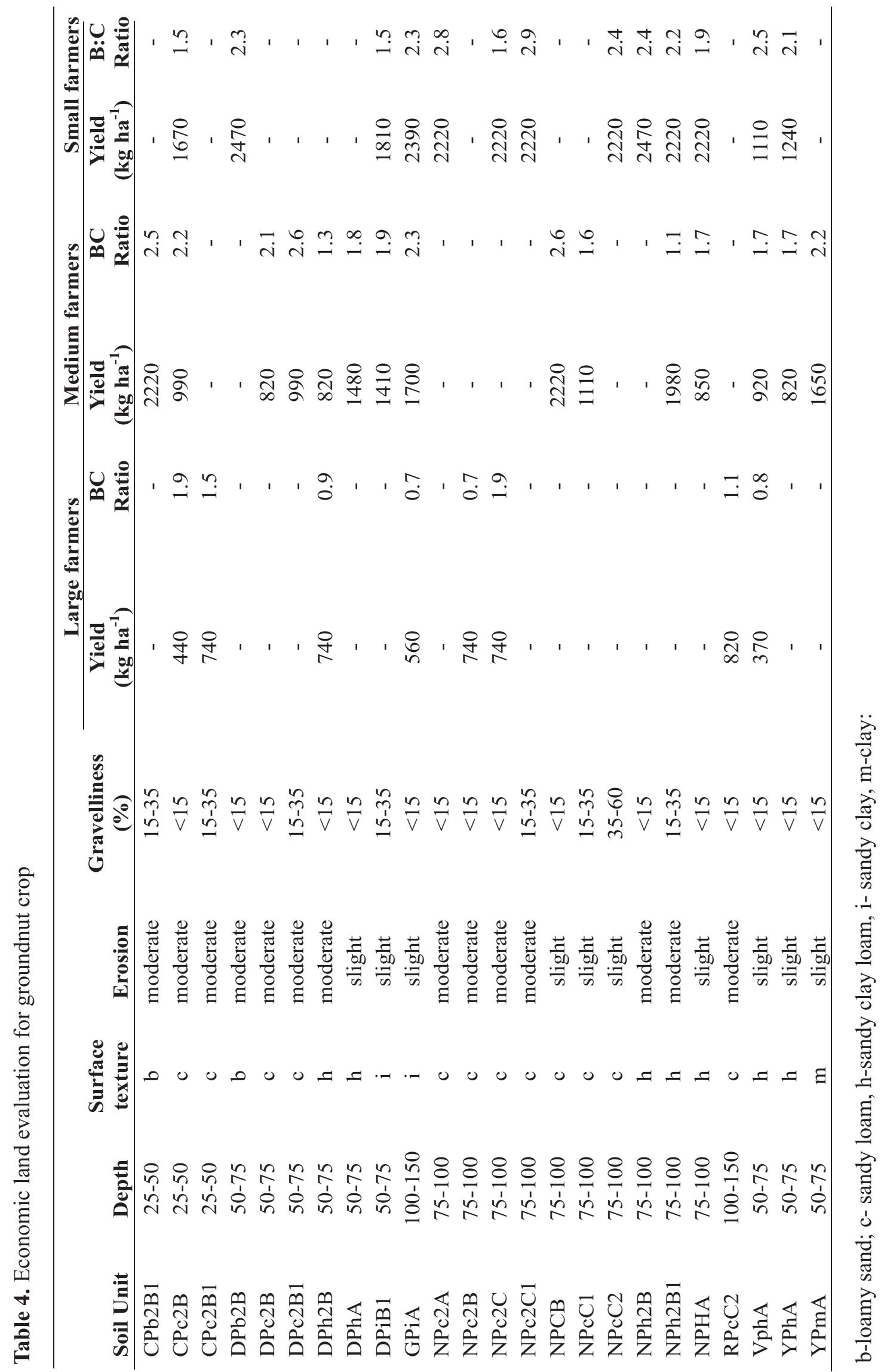




\section{LOCATION MAP OF BUKKARAYASAMUDRAM MANDAL}

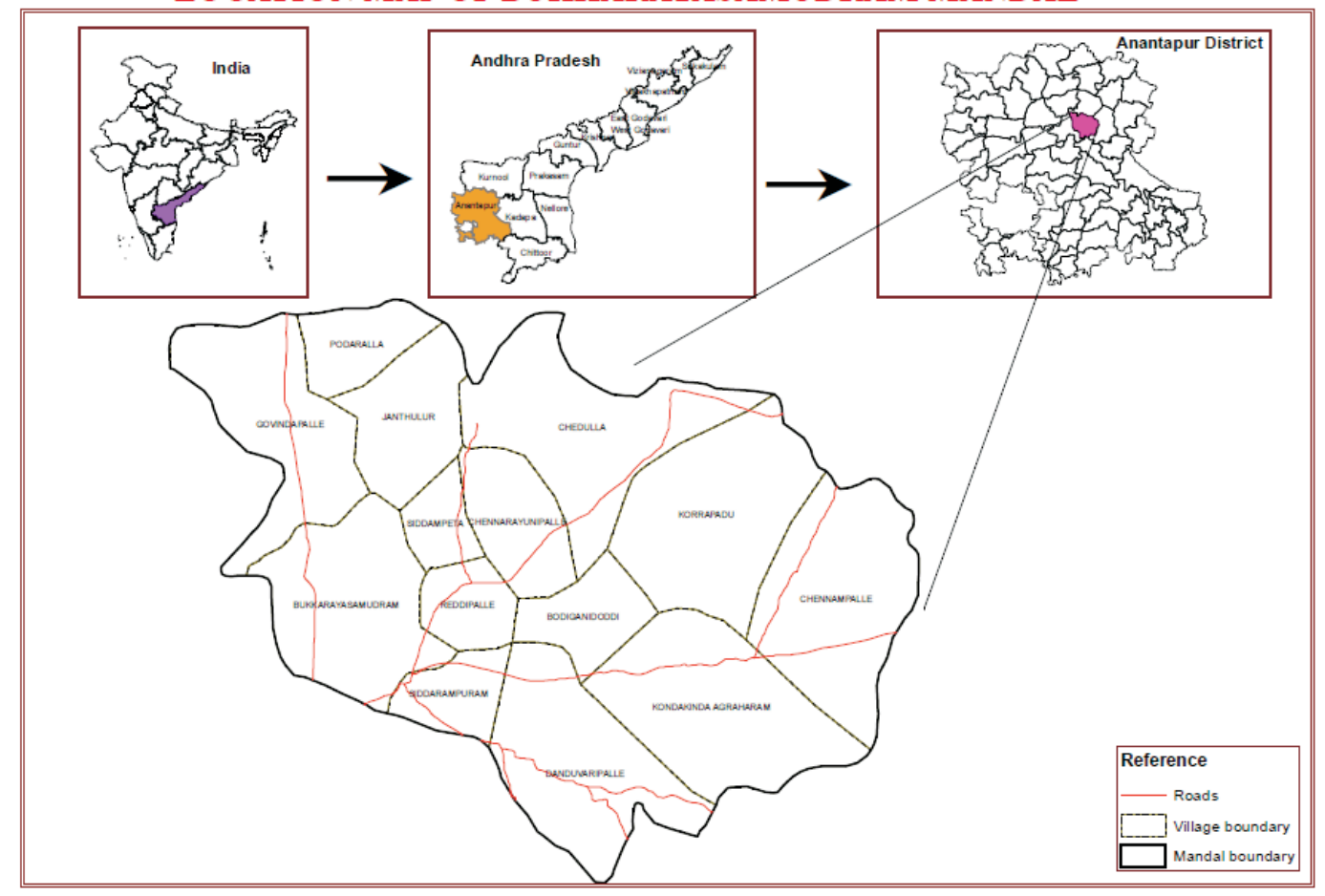

\section{References}

Arshad, M. A. and Martin, S. (2002). Identifying critical limits for soil quality indicators in agro ecosystems. Agriculture, Ecosystems and Environment 88, 153-160.

Dharumarajan, S. and Singh, S. K. (2014). GIS based soil site suitability analysis for potato - A case study in lower Indo- Gangetic alluvial plain. Potato Journal 41, 113-121.

FAO (1983). Guidelines: Land evaluation for rainfed agriculture, Soils Bulletin, 52, Rome.

Jackson, M. L. (1973). Soil Chemical Analysis. Prentice Hall of India Pvt. Ltd. New Delhi

Lalitha, M., Dharumarajan, S., Natarajan, A., Niranjana, K.V., Srinivas, S., Naidu, L.G.K. and Sarkar, D. (2016). Need for site specific land resource database for integrated watershed management. Indian Journal of Soil Conservation 44, 168-176.

Madhusudhana, B. (2013). A survey on area, production and productivity of groundnut crop in India. IOSR. Journal of Economics and Finance (IOSR-JEF) 1, 1-7.

Naidu, L.G.K., Ramamurthy, V., Chella, O., Hegde, R. and Krishnan, P. (2006). Manual for soil site suitability criteria for major crops. National Bureau of Soil Survey and Land Use Planning, Technical Bulletin No. 129, Nagpur.

Natarajan, A. and Sarkar, D. (2010). Field guide for soil survey. National Bureau of Soil Survey and Land Use Planning, Nagpur. pp.73.

Naveen, P. (1991). An analysis of Anantapur climate. International Crop Research Institute for the Semi-Arid Tropics, Hyderabad, India.

Soil Survey Staff (2003). Soil survey manual. (USDA, Scientific Publishers, Jodhpur).

Virmani, S. M. and Shurpali, N. J. (1999). Climate prediction for sustainable production of rainfed groundnuts in SAT: crop establishment risks in groundnut production in the Anantapur region. Technical Manual no. 4. International Crops Research Institute for the Semi-Arid Tropics.

Walkey, A. and Black, I. A. (1934). An estimation of the method for determining soil organic matter and a proposed modification of the chromic acid titration method. Soil Science 37, 29-38.

Received: June, 2018 Accepted: October, 2018 